\title{
Sources, Stigmatization, And Alleviation Of Poverty In Albany/Dougherty, Georgia
}

\author{
Amaechi N. Nwaokoro, Albany State University, USA
}

\begin{abstract}
The objective of this study is to highlight the impacts of and solutions to the major sources of poverty in the City of Albany and Dougherty County, Georgia. White, as well as Black middle class residents, are leaving the City of Albany and Dougherty County to the other Albany MSA counties that are experiencing increase in commercial activities and median family incomes. This movement seems to reflect increasing City vices and very low educational achievements from the public school system. These along with a low consideration of the county for professional careers, lead to depressed business opportunities that cause exit of businesses. Cautiously speaking, depressed employment and a low real average weekly wage earning, a proxy for poverty, explain the poverty. There is a need for specialized micro financial lending especially in the impoverished areas of the county. Poverty is being addressed by some temporary measures. In the long run, individuals' understanding of how market economy works would resolve poverty.
\end{abstract}

Keywords: Poverty; White-migration; Restricted-economy; Stratified-economy; Segregated-economies; Dualisticeconomy; Purchasing-power disparity; Impoverished-environment; Poverty-alleviation; Economic-inequality; Wealth Flight Population; Micro-finance lending

\section{INTRODUCTION}

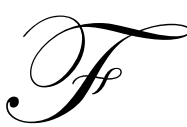
ounded close to the Flint River in the early 1800s, Dougherty County with a 2010 population of $96,065^{1}$ is still rural and agricultural. Though the City of Albany/Dougherty County is economically distressed, it is still considered the industrial, retailing, and service hub of Southwest Georgia. Particularly, small businesses on the east-side of the county (East Albany), engage mostly in retail and services. The county is remotely located from Georgia's major metropolitan area of Atlanta and from other industrial cities. A few larger establishments in the Albany MSA provide most of the area's employment opportunities ${ }^{2}$.

Since the 1970s, White residents and businesses have been leaving the City of Albany and Dougherty County. White migration to other counties seems to be a response to Dougherty County's student low educational achievement and higher orders of City crimes ${ }^{3}$. A superior suburban education is sought after to achieve a superior human capital that is the basis of favorable differential earnings in the labor market (D'Amico and Maxwell, 1994 Gittleman \& Wolff 2004). Whites would likely seek to maintain this advantage given an increasing application of anti-discriminatory laws in the labor markets. The restricted economy of Dougherty County seems to give rise to the cited crimes.

The migration from Dougherty County is also taking the middle-income Blacks to the rural counties leaving Dougherty County, and most especially, the City of Albany, with the poor, working poor, and those who have less market-based skills (Adams-Cooper, 2011). The migration is leading to distressed economic conditions in the county. Blacks represent $60.1 \%$; while Whites and Hispanics comprise $37.34 \%$, and $1.3 \%$ respectively of the

\footnotetext{
${ }^{1}$ The estimate is retrieved from: http://doughertycounty.georgia.gov/03/home/0,2230,8466851,00.html

${ }^{2}$ The largest establishments are retrieved from:

http://explorer.dol.state.ga.us/mis/historical/qcew/top employers/top10/albany09q1.pdf

${ }^{3}$ These indexes are accessible at: http://services.georgia.gov/gbi/crimestats/viewCrimeStatReport.do
} 
overall Dougherty County population ${ }^{4}$. Between 1970 and 1980, the City of Albany had a population growth of $28 \%$ while the Albany MSA had a population growth of $69 \%$. From 1990 to 2000, the City of Albany had a population decrease of $2 \%$ while Albany MSA gained a population growth of $8 \%$ (Farr \& Slade, 2008). Within Dougherty County, the Black population is more concentrated on the east-side and south-side. Sub-continental Indians, Whites, and Koreans participate actively in the economic activities in the mostly African American neighborhoods.

The sources of poverty have cumulatively led to depressed growth of the establishments, of a low consideration of the region for professional careers, and of low real average weekly wages in the labor market. Distressed economic conditions, including abject poverty are the outcome of the complex realities in the county.

Since three-fourths of all earnings is wage compensation, it is reasonable to address poverty here from the perspective of the variation in the labor market's real average weekly wages and from the levels of employment, unemployment rates, and establishments (Mankiw, 2008, p 391, Lardner and Smith 2005, p 31). An economy that experiences positive growth in the number of wage earners and in wage compensations is most likely to diminish poverty.

The objective of this study, therefore, is to explore and highlight Dougherty County's sources of and solutions to poverty by showing the status of the real average weekly wage earning (a proxy for poverty). Related poverty indexes are shown as evidences of the hard economic realities in the county. Cautiously speaking, the sources of poverty tend to cause the exit of the big establishments, a declining employment, and a slight increase in the real average weekly wage earning. The real average weekly wage earning tends to rise slightly as fewer people are working. The following entails the remainder of the study. Section II handles the discussion on the sources, effects, and alleviation of poverty. Section III centers discussion on research methodology and results. Section IV presents the implications on minority entrepreneurship to diminish poverty and Section V handles the conclusion. I relate this research to poverty discussion in Owen \& Martinez (2008), Hoynes (2006), Theodos, and Bednarzik (2006), D’Amico and Maxwell (1994), and Smith and Vavrichek (1987).

\section{SOURCES OF POVERTY}

Dougherty County exemplifies poverty that characterizes the southern United States which has one-thirds of the U.S. population, but roughly $40 \%$ of U.S. poor (Riddell et al. 2011, p 269). As in Gittleman \& Wolff (2004), the poverty in the rural and agricultural Dougherty County has given rise to class stratification ${ }^{6}$ in a restricted economy and this explains that economic opportunities are not within the reach of the poor.

As in Davis \& Balazs (2011), one of Dougherty County's sources of poverty is a situational factor. The county is remotely located from Georgia's major metropolitan area of Atlanta and from other industrial cities. It takes roughly three and a half driving hours to travel from the City of Albany, the capital of the county, to the City of Atlanta, Georgia. Also, it takes roughly two and a half driving hours to travel from this city to the industrial City of Tallahassee, Florida. The long distances to these cities restrict the access of many Dougherty County residents to information, capital, and other economic opportunities. Poverty expanded most especially in East Albany in the middle of the 1970s with the paving of the Georgia's portion of the Interstate 75 that runs roughly 40 miles east of Albany. Since the construction, new development has occurred close to this Highway (Farr \& Slade, 2008).

Contrary to Couch and Daly (2002), the economy of the county is not inclusive and is not growing to reduce poverty and inequality. Economic inequality leads Albany MSA to observe a huge purchasing- power disparity that is explained by a mean ratio $^{7}(0.545)$ of Black to White purchasing power (Baldwin and Johnson

\footnotetext{
${ }^{4}$ The estimates are retrieved from: http://www.city-data.com/county/Dougherty_County-GA.html.

5 The estimates are obtained from: Hodler \& Schretter 1986. "The Atlas of Georgia, The Institute of Community and Area

${ }^{6}$ Agriculture does not yield substantial income. At the Federal level, roughly 52\% of farmers earn more than $\$ 8.00$ per hour (Theodos and Bednarzik 2006, p.36).

7 This empirical information comes from the purchasing power data of The University of Georgia, Terry College of Business, Selig Center for Economic Growth.
} 
1996). This disparity is generally explained from two opposing perspectives. The opposition to income inequality comes from reality instead of morality. The argument is that a large inequality would cause both social and political chaos. Given these, the members of the poverty class could, for example, endorse trade restrictions that might cause inefficient allocation of resources. A vast poverty class with a lot of uneducated members would put any economy at a disadvantage in a global economy (Bagi 2008).

Supporters of income inequality stand on the ground that income inequality provides an incentive for competition and hard work required for an expansionary economy. The support for income inequality suggests that those who work hard and are creative and successful must be rewarded at high levels. They claim that most people are better off with a huge difference between the rewards of winners and losers. None of these perspectives is entirely supported by this study. This study upholds competition and recognizes that there are people that cannot naturally compete and that competition may not always lead to successful rewards. Poverty, therefore in the situation of Dougherty County, is mostly explained by its own peculiar factors that may not characterize some other counties.

Poverty is more highly pronounced on the east-side of the county that is mostly African American (91\% of the population) and has a poverty rate of $45 \%$ (Farr \& Slade 2008, Mankiw 2008, Hoynes et al. 2006). Given this poverty rate, there would be a persistent poverty in East Albany if the poor are unable to embrace enough education and are not cognizant of how wealth can be maximized from economic markets (Lui et al 2006).

Another source of the persistent poverty in Dougherty County is the low level of educational achievement. This source may have adversely impacted on the market related skills as in Browne (1997). Education, as an income equalizer ought to be a pathway out of poverty since it is positively correlated with productivity and earnings (Theodos and Bednarzik 2006, p.43). An educated population is likely to advance the production of goods and service, and opportunities for others. The high school graduation and dropout rates of $57.44 \%$ and $6.39 \%$ respectively would describe a low level of market related skills in the City of Albany/Dougherty County ${ }^{8}$.

In poverty stricken East Albany, $40.0 \%$ of the adults do not have high school diplomas and an insignificant $5.8 \%$ of the adults have college degrees (Farr \& Slade, 2008). D'Amico and Maxwell (1994) note that Black youth's wage converges to that of the White's whereby the Black youth makes a smooth shift from school to work. Given the current high-school graduation and dropout rates in the Dougherty County School System, this kind of wage convergence would not be achieved. While effective education enhances human capital accumulation that promotes non-market discrimination, a defective one will not only inhibit entrepreneurial visions, it will also create a non-market discriminatory low wage (Theodos \& Bednarzik 2006, Gardner \& Hern 1992).

Browne (1997) identified a huge gap in pay between White and Black women. This gap is explained by relatively high number of Black women than White women that is family heads with low level of education. Declining educational achievement, stagnant poverty, and vices may have led to a very low human capital accumulation that explains a low level of entrepreneurial activities. This assertion is evidenced by the vast presence of businesses owned by sub continental Indians, Whites, Koreans, and Chinese in the mostly African American neighborhood on the east-side of the county. Here, most of the prominent establishments owned by African Americans are faith based initiative institutions. These institutions are relatively easier than for-profit-businesses to establish due to their low capital intensiveness.

An absence of harmonized macroeconomic development in the county leads to dualistic economic environments - east and west Dougherty County. Mostly, economic development takes place on the west-side of the county. The east-side of the county (East Albany) contrasts the west-side. Generally, Blacks do not own businesses but do own churches on the west-side of the county. The dualistic economic nature of the county should not have taken place if every part of the county is articulated to accomplish a harmonized regional development. Given that the poor communities have relatively higher marginal propensity to consume (MPC), the east-side ought to be articulated to harmonize development (Ballard 2008).

\footnotetext{
${ }^{8}$ Dougherty County School System provided these estimates.
} 
The county faces a challenge posed by crimes. Between 2000 and 2010, the total number of higher crimes in the county that range from vehicle theft, larceny, burglary, assault, robbery, rape, and murder increased by $17 \%$. Also, during the period studied, the number of criminals admitted into jails exceeded the number of criminals released ${ }^{9}$. Other things being equal, this situation could explain increase in the number of jails, tougher and longer sentences that reflect the State of Georgia's minimum mandatory sentences. The minimum mandatory sentences send felons that repeat some special crimes to longer imprisonment term. The high levels of crimes could be cumulative effects of low education, poverty, lack of relevant market skills, hedonic activities, and institutional discrimination.

White migration out of the county instigates poverty. The movement removes both White entrepreneurship and money resources out of the county. The White rural migration has led to a lot of unoccupied buildings mostly in the downtown areas of the City of Albany. Given that Whites have high educational endowment that commands favorable non-discrimination status in the labor market, high financial endowment and entrepreneurship; accordingly the Whites have been the major employers of labor. These attributes are lost due to White migration. The public school system and most of the colleges in the county have mostly African American student populations. This non- diversified environment would reduce both aggregate expenditures and aggregate incomes, prevents a robust student population, and diminishes group dynamism and strength in pluralistic, cultural, and human diversity. Poverty is therefore the consequence.

Along with the White relocation is an exodus of some of the prominent establishments and small businesses out of the county. Poverty as a result expanded when the biggest employers like Firestone, the US. Naval Air Station and Merck Pharmaceuticals moved out of the county. Also, a lot of small businesses left the City of Albany and the county as other counties in the Albany MSA experienced increase in population and commercial activities. As in (Schmitt 2004), the outcome of the exit of these establishments from the county has lead to involuntary job displacements and declined employment.

Specialized micro financial establishments are not common especially in the east-side of the county. These institutions have been proven to have led to poverty reduction and for elevating financial awareness especially in the impoverished environment (Morduch 2002, Khandker 2005). Just as it takes the appropriate level of exogenous investment to induce an expected economic growth, it could require the impact of micro financial establishments most especially in the restricted and impoverished economy to effect a reduction in both unemployment and poverty rates. These institutions will introduce economic developmental shocks that could be the precondition for poverty alleviation.

Unlike the conventional financial intermediaries (commercial banks, credit unions, and savings and loan institutions) that require some compensating balances from borrowers, and have rigged, detailed, and restrictive contracts, micro financial establishments will undertakes specialized financial functions that strictly target the needs of the poor and working poor. The primary function of the establishments will be to provide concessionary small scale or soft loans for financing businesses like mom and dad pubs. By bringing financial process closer to the poor, they will be more aware that there is a cost (interest rate) that must be paid to obtain scare monetary resources to create or finance existing businesses. This market attribute will improve citizenry welfare with their increasing participation in the financial markets. Secondly, the creation of these institutions will provide more insight to the residents on the functions of money as a medium of exchange, a store of value, and a unit of account. Increased financial awareness will effect a reduction in poverty as the residents become more and more able to express expected benefit, opportunity cost, and scarce resources in monetary terms.

Monetarizing an impoverished environment could encourage the residents increased long run participation in higher levels of financial markets-bonds and stocks. Monetarization would financially revolutionize impoverished environments, create job opportunities, increase savings to reduce the high propensity to consume (MPC) associated with impoverished environments. Also, the poor would observe monetary saving by working in the area of residency. In a nutshell, crimes, unemployment and poverty rates would reduce whereby the impoverished environment becomes less restricted and stratified, and the poor is able to access increasing economic

${ }^{9}$ These indexes are accessible at: http://services.georgia.gov/gbi/crimestats/viewCrimeStatReport.do 
opportunities.

The average unemployment rate in the county has increased from about $7.4 \%$ in the early 1990 's to over $10.2 \%$ in $2009^{10}$. The high unemployment rate in the restricted Dougherty County contradicts Davis et al (2006) that worker flows and job flows at the micro level are roughly unchanged during business cycles. If national unemployment rates highlight the realities at the micro levels, the impact of unemployment would be heavier on Black majority group in this county. Nationally, the unemployment rates for Blacks is about double that of the unemployment rate of Whites. The national unemployment rates in 2008 are $9.2 \%, 6.4 \%$, and $4.4 \%$ for African Americans, Hispanics, and White respectively. By January 2010, the respective rates are: $17.50 \%, 12.6 \%$, and $9.50 \%$ (Blitzer, 2010). Though racial groups' unemployment rates do not exist at the county level, it is clear at the macro level that unemployment rate has a disproportional adverse impact on minorities, for African Americans in particular.

Also, consistent macro estimates from 2000 to 2007 indicate that both employment and incomes of African Americans declined roughly by $3 \%$. Also, since the current "Great Recession" commenced, African Americans have experienced a $15 \%$ unemployment rate in comparison with a $9 \%$ unemployment rate for whites. With a relatively low minority saving rate, it is clear that minorities bear a disproportional share of recession disturbances in comparison with their white counterparts (Graham 2009). These estimates highlight the fact that minorities, especially African Americans, experience a depression when White Americans experience a recession. The growth areas in the Dougherty County are education, health care, and defense service (Farr \& Slade 2008).

Both institutional discrimination and social segregation explain segregated economies and the associated poverty in the county. Blacks are clustered mostly on the east-side and south-side of the county where the respective economies offer limited economic opportunities. These economies do not have the middle class individuals that can foster a market based economies and opportunities for others. The residents of the poverty stricken areas may not have access to employment opportunities in the west-side if they lack private transportation or have to walk long distances to access public transportation. As in Castillo (1998), personal transportation and other personal problems do cause job search discouragement. It is clear that dualistic economies lose the substantial benefits of economies of scale.

Social class driven by income causes its own segregation. The rich and middle class individuals including White and Black live on the west-side of the county if they choose not to migrate to the other Albany MSA counties. This socially driven segregation based on income tends to prevent interaction between the elite class and the poor who may want to learn entrepreneurship. Intergenerational poverty and crime seem to have become the outcomes of the current non diversified economy of Dougherty County. Unless discrimination is minimized mostly by education, poverty will persist.

In a nutshell, various factors lead to the stagnant poverty in the Dougherty County. Currently, 25.3 percent of Dougherty County residents are below the poverty income level. This rate is higher than the State of Georgia's poverty rate, $14.7 \%{ }^{11}$. In 1969 , the City of Albany's poverty rate was $24.4 \%$. By 1979,1989 , and 1999 the poverty rates were $24.3 \%, 27.5 \%$, and $27.1 \%$ respectively at the city level. At the Albany MSA level the 1969 poverty rate was $23.4 \%$ and by 1979,1989 , and 1999 , the rates were $20.4 \%, 22.8 \%$, and $21.4 \%$ respectively ${ }^{12}$. The annual incomes of the working poor may reach below the 2005 poverty income level of $\$ 19,971$ established for a family of four (Schiller, 2008) with a continuous decline of the economy. Overall, the sources of poverty in the county tend to inhibit the objective of the Personal Responsibility and Work Opportunity Reconciliation Act of 1996 that emphasizes work to achieve poverty alleviation.

\section{II.1. Effects of Poverty}

People are chastised and stigmatized by the ravages of poverty (Browne 1997). Poverty could be seen as

\footnotetext{
${ }^{10}$ Source: Georgia Department of Labor

${ }^{11}$ The estimates are retrieved from: quickfacts.census.gov/qfd/.../13177.html and quickfacts.census.gov/qfd/.../13095.html

${ }^{12}$ Source: htt://socds.huduser.org/Census/incpov.odb
} 
an epidemic disease that affects every aspect of an individual's life. Poverty can lead to a compromise or loss of one's human freedom. Recognition of the detriment of poverty has led the U.N. to declare war on poverty. Poverty impacts on the social, political, and economic status of the citizens. Socially, the poor have limited opportunity to interact with the rich. This limited opportunity is capable of decreasing the entrepreneurship learning curve of the isolated poor. Therefore, the poor will socialize among themselves around non-market events that could cause social problems. These events could include but are not limited to preference for public assistance, crime, incarceration, and drug distribution and consumption (O'Connell \& Sheikh 2008, Browne 1997). Where these dominate, the poor may not be able to cease the opportunities presented to them.

Politically, the poor are likely to make uninformed choices and have less participation in a political environment. Uninformed choices could lead to exercising political actions that are capable of harming the poor. A low participation of the underclass in a political environment could result in the election of politicians who may not understand the plight of the poor. Since the poor cannot easily mobilize in a democracy, the situation can be a perpetual ignored poverty. Democracy will therefore diminish where the poor experience a loss of political rights and responsibilities.

Economically, poverty means a state of deprivation that is characterized by low or no income. Low or no income leads to a low quantity and quality of goods and service consumed. These kinds of consumption have their implications in human development. Both physiological and mental development could be adversely affected by a poverty driven environment where hedonic values might prevail. Homelessness, crimes, low-birth weight babies, increased illness, family disintegration, and lower productivity have been linked to poverty. Also, chronic diseases such as stroke, heart ailments, and cancer have been linked to health disparities within poor members of minority groups (Riddell et al. 2011, p. 269, Lardner and Smith 2005, pp105, 113, Owen \& Martinez 2008). Thus, the real incidence of poverty imposes significant costs on society.

\section{II.2. Poverty Alleviation Initiatives}

A variety of measures and initiatives are in place to combat poverty at the state, regional, and local levels. The Georgia Rural Development Council conducts poverty assessments from the poorest areas of the state and makes policy recommendations to the governor who uses the recommendations to initiate rural economic development. The Center for Rural Entrepreneurship, the Rural Health Association, and USDA engages in various activities. The Rural Entrepreneurship assists in the innovative development of local entrepreneurs that would have development spread effect on the local economy. The entrepreneurs are seen as innovators who in the process of their Schumpeter entrepreneurial activities will improve the economic confidence, wage, and opportunities in their particular rural area.

The Rural Health Association advises the rural population on preventive medicine, environmental awareness, and on proper nutrition and balanced diet. The USDA assists local farmers with information and research to enhance productivity and profitability. The Department could assist farmers by recommending appropriate technologies to affect a high level of productivity. With the Department, the farmers could attract favorable price for their produce to maximize profitability.

The Mayor of the City of Albany announces through the radio, access to GED education to reduce illiteracy. Utilization of this program will spur the awareness levels of the beneficiaries. It would be easier, therefore, to train people in productivity functions, given their advanced levels of awareness. Higher levels of educational awareness would enable adequate political, economic, and social choices. Crimes may be minimized as a result of increased awareness.

Other organizations in the urban areas that provide assistance and advice include Habitat for Humanity, Food Bank of Southwest Georgia, Albany-Dougherty Community Partnership for Education Inc. Habitat for Humanity provides shelters and food, and Food Bank of Southwest Georgia provides food to the poor. Dougherty Community Partnership for Education Inc.- a partnership between some members of the local community and the local schools, aims at improving the declining academic standards of the local schools, and minimizing crimes. 
Politicians target an increased minimum wage to achieve a livable wage that minimizes poverty especially on the part of the working poor. Minimum wage has increased several times since it was enacted in Fair Labor Standards Act of 1938 (Smith and Vavrichek 1987). Currently at \$7.25 per hour, some feel that the minimum wage has not gotten to its anticipated status of livable wage. A classical unemployment that is associated with minimum wage tends to weaken the arguments in favor of achieving the expected livable wage to avoid incomes going below the poverty income line.

The cited poverty alleviation measures are seen as temporary measures by this study. Micro-finance lending could spur the economy toward the long run economic growth. Poverty would end in the long run when most people have a clear understanding of a market economy. At the county level, an economic institute to be known as Business Enterprise Institute has to be established. This institute will provide a college graduate, on a pragmatic basis, the detailed concepts of resource scarcity from both the perspectives of producer and consumer. The graduate will understand that resources are sold and bought because they are scare relative to the demand for the use of them. The resources, vision, mission, and objectives of the institute must strictly relate to the understanding of the attributes of a market economy.

Understanding the concept of resource scarcity will guide would-be-entrepreneurs on the need to use resources wisely. They will understand that employing the productive resources in a production process will require the best judgment and innovative efficiency that minimize waste. Minimizing waste will enable the most expected outcome from the resources. The would-be-entrepreneurs or risk takers of the Institute will also empirically understand the detailed resources constraint faced by the consumers that are expected to be rational. Rationality compels the consumers to be frugal, save some money out of income for investments, and to choose low prices in order to get the most purchases out of the scarce income.

The instruction of the Institute will communicate to would-be-risk takers the process of profit maximization that requires the thinking at the margins when conducting economic activities. Thinking at the margin seems to be very difficult to comprehend from the theory. It becomes clear where the process is handled from the empirical perspective. The would be-risk taker will understand that economic profit or gain increases if additional economic activity to be undertaken will add more to the existing total benefit than it does to the existing cost. In order words, extra activity is worthy to be undertaken if the extra activity adds more to total benefit than it does to cost. The most profit or gain is realized at the point where an extra activity adds the same amount to total benefit as it does to cost. Beyond this point, profit or gain will decrease as an extra activity will add more to cost than it does to total benefit. Marginal analysis is a very fundamental economic mandate that a lot of people find difficult to comprehend.

The Institute will communicate the fundamental objective of business partnership that is basically an opportunity to underwrite high cost outlay that is beyond the resource of a single entrepreneur. Sources of business financing that range from personal savings to bank loans will be empirically communicated by the Institute. This short statement here is most likely to lead to substantial poverty alleviation in the long run.

\section{RESEARCH METHODOLOGY AND RESULTS}

The yearly data on the variables that describe the real average weekly wage (poverty) in the county covers mostly the period from 1990 to 2008. Since the series in the data ended in 2008, the most current and relevant empirical estimates are cited to compare with the related previous estimates. These variables are retrieved from various sources. The wage and establishments variables ${ }^{13}$ retrieved from the Georgia Department of Labor: Historical Data are average weekly earnings, and average number of establishments of all industries. The real average weekly earnings variable constructed from the average weekly earnings is basically a proxy for poverty from Dougherty County stratified economy that provides restricted opportunity.

The county's variables on employment and unemployment rate, crimes indexes, and criminals admitted and released from jails, are respectively retrieved from Georgia Department of Labor, Georgia Bureau of Investigation, and Georgia Department of Correction. The crimes index is the sum of all crimes committed. The difference

\footnotetext{
${ }^{13}$ Source: http://explorer.dol.state.ga.us
} 
between the number of criminals admitted to and released from jails is a factor that could describe whether or not a felon is able to find employment. Dougherty County School System provided the high school graduation and dropout rates. Poverty estimates are cited from other studies since the county does not have a yearly series on the variable. The descriptive statistics of the major series ${ }^{14}$ are presented in Table 1 below:

Table 1: Summary statistics

\begin{tabular}{|l|c|c|c|}
\hline \multicolumn{1}{|c|}{ Variable Name } & Dougherty County & City of Albany & Albany MSA \\
\hline Avg. Weekly Earnings & $\$ 534.05$ & & \\
\hline Median Weekly Earnings & $\$ 541$ & & \\
\hline Avg. Unemployment. Rate & $6.95^{\mathrm{a}}$ & $7.53^{\mathrm{a}}$ & \\
\hline 2008 Unemployment Rate & $6.9^{\mathrm{b}}$ & $7.3^{\mathrm{b}}$ & $6.3^{\mathrm{b}}$ \\
\hline 2009 Unemployment Rate & $10.2^{\mathrm{b}}$ & & $9.4^{\mathrm{b}}$ \\
\hline 1970 Poverty Rate & & $28.5^{\mathrm{c}}$ \\
\hline 2000 Poverty Rate & $24.8^{\mathrm{d}}$ & $21.5^{\mathrm{c}}$ \\
\hline 2010 Poverty Rate & $22.3^{\mathrm{c}}$ & & \\
\hline Avg. Establishments & 2634.63 & & \\
\hline Observations: 19 & & & \\
\hline
\end{tabular}

${ }^{\mathrm{a}}$ This is an average rate from the period 1990-2008 studied.

${ }^{\mathrm{b}}$ These rates come from Georgia Department of Labor.

c These rates come from: "Albany, Georgia: the East Albany neighborhood".

${ }^{\mathrm{d}}$ This rate comes from: http://www.ecanned.com/GA/Dougherty_County.shtml.

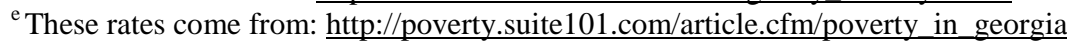

Figure 1: Time series Plots for the Real Average Weekly Wage, Establishments, Employment, and Unemployment Rate

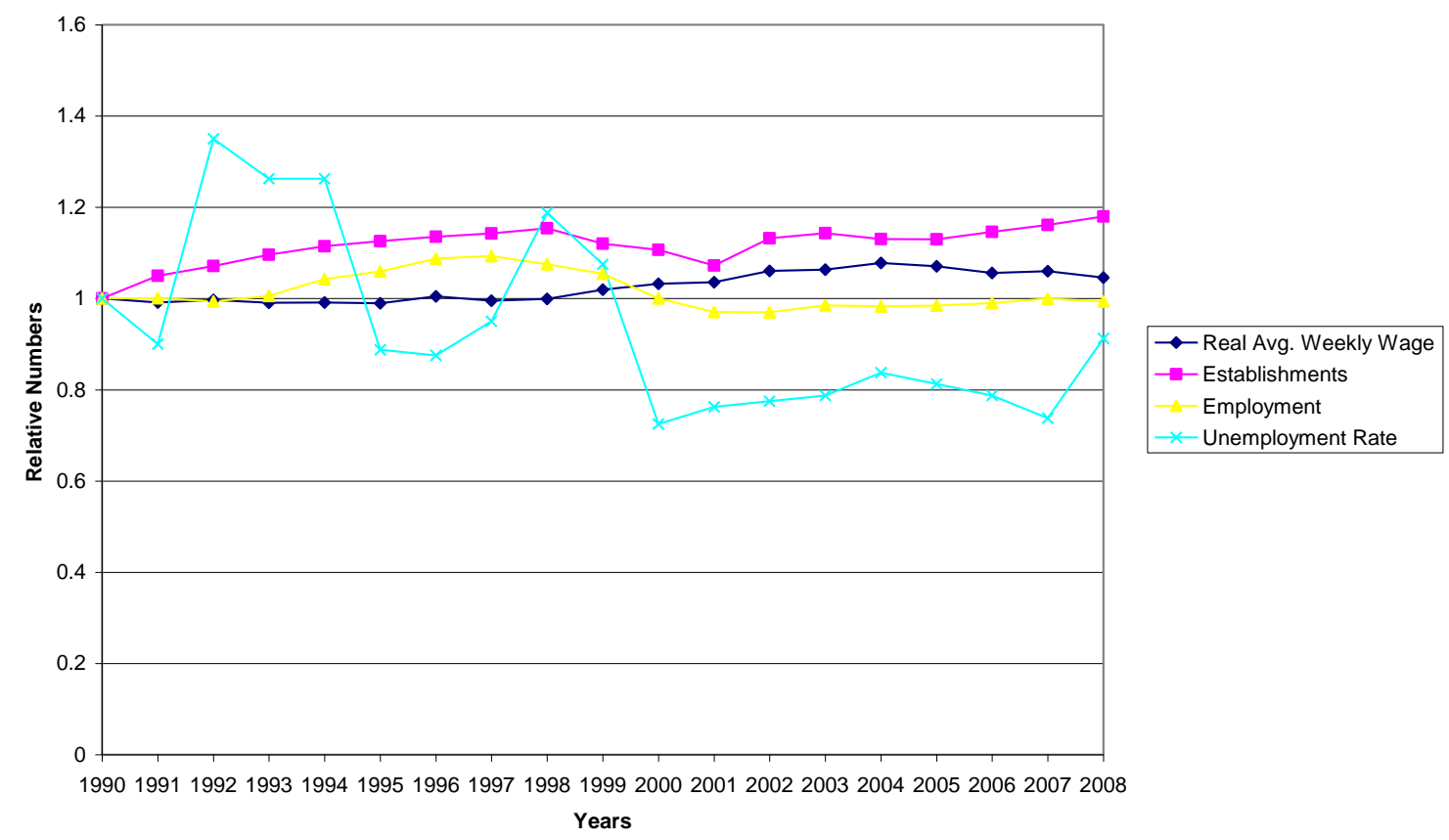

Figure 1 shows the time series plots from the relative values ${ }^{15}$ for the real average weekly wage earnings,

\footnotetext{
${ }^{14}$ The average weekly wage earnings series is normalized by bringing its values to its 1990 constant values as handled at: http://www.dollartimes.com/calculators/inflation.htm

${ }^{15}$ Define a relative value as $\mathrm{X}_{\mathrm{t}} / \mathrm{X}_{1990}$ where $\mathrm{X}_{\mathrm{t}}$ is the observation of period $\mathrm{t}$ and $\mathrm{X}_{1990}$ is the base year's observation. Sources: see the discussion of the variables on Section III.1.
} 
level of establishments, employment, and unemployment rate.

The establishments' variable has a relatively increasing trend from 1990 to 1998 and declines slowly until 2001. It rises gently until 2003, and declines slowly until 2005 and starts rising slowly again. During the period in study, establishments increase by $0.94 \%$.

A general increasing trend describes the employment variable from 1990 to 1997 and then declines until 2001 where it starts a slowly increasing trend. A general increasing trend of the establishments' variable seems to characterize the general increasing trend of the employment variable.

Generally the unemployment rate variable is very volatile. Specifically, from its lowest level in 1991 it depicts a rapid increase up to 1992 and declines slowly until 1993. It is steady until 1994 and declines rapidly until it gets to the lowest level in 1996. From here, it shows a rapid trend until 1998, goes down sharply until 2000 and except in 2005-2007 period when it declines, it portrays a slowly increasing trend.

The real average weekly wage variable's trend is mostly flat from 1990 to 1998 , and it rises slowly until 2006 and shows a slight decline afterwards. Except in 2001, the trend of the real average weekly wage generally reflects the increasing trend of the establishments' variable. Also, the trend of the real average weekly wage variable is generally an opposite trend of the employment variable. Relative to the percentage increase in establishments $(0.94 \%)$, the employment declines by $0.02 \%$ and the real average weekly wage increases by $0.25 \%$.

The following graphs present characteristics of the economic stagnation in the City of Albany, Dougherty County, and Albany MSA. Figure 2 presents the unemployment rates ${ }^{16}$.

Figure 2: Unemployment Rates in the City of Albany, Dougherty County, and Albany MSA

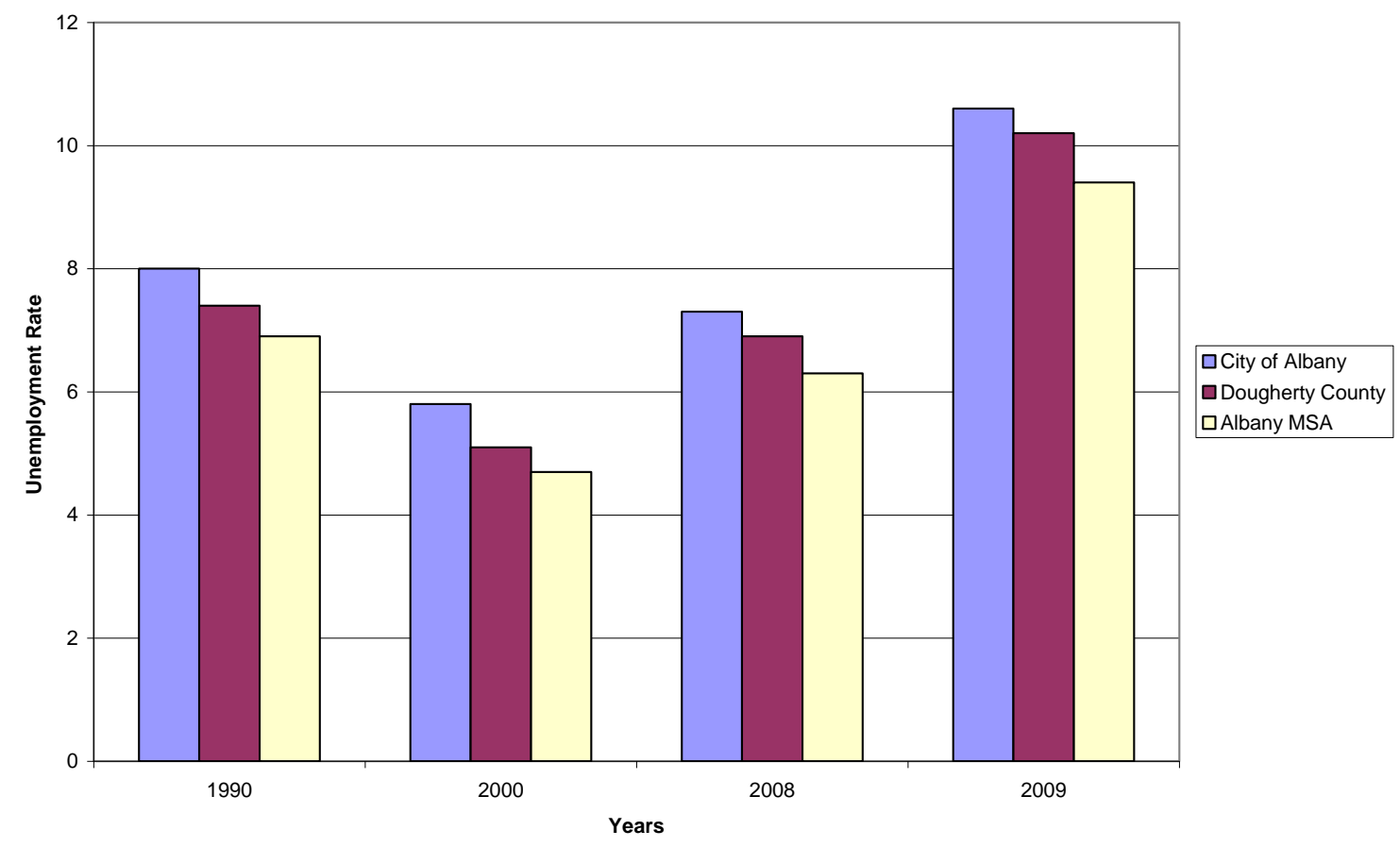

The chart clearly shows higher unemployment rates at the city and county levels. The 2009 rates from the City of Albany (10.6\%) and Dougherty County (10.2\%) are respectively higher than the state's rate $(9.6 \%)$. With this statement and the empirical fact that the 2009 Albany MSA unemployment rate (9.4\%) is a little lower than the

${ }^{16}$ Source: Georgia Department of Labor. 
state's rate, are indications of the expanding commercial opportunities in the other counties of Albany MSA that the Wealth Flight populations, White and Black are relocating to. Most of the relocation is from the City of Albany.

Figure 3 presents the poverty rates $^{17}$.

Figure 3: Poverty Rate in the City of Albany and Albany MSA

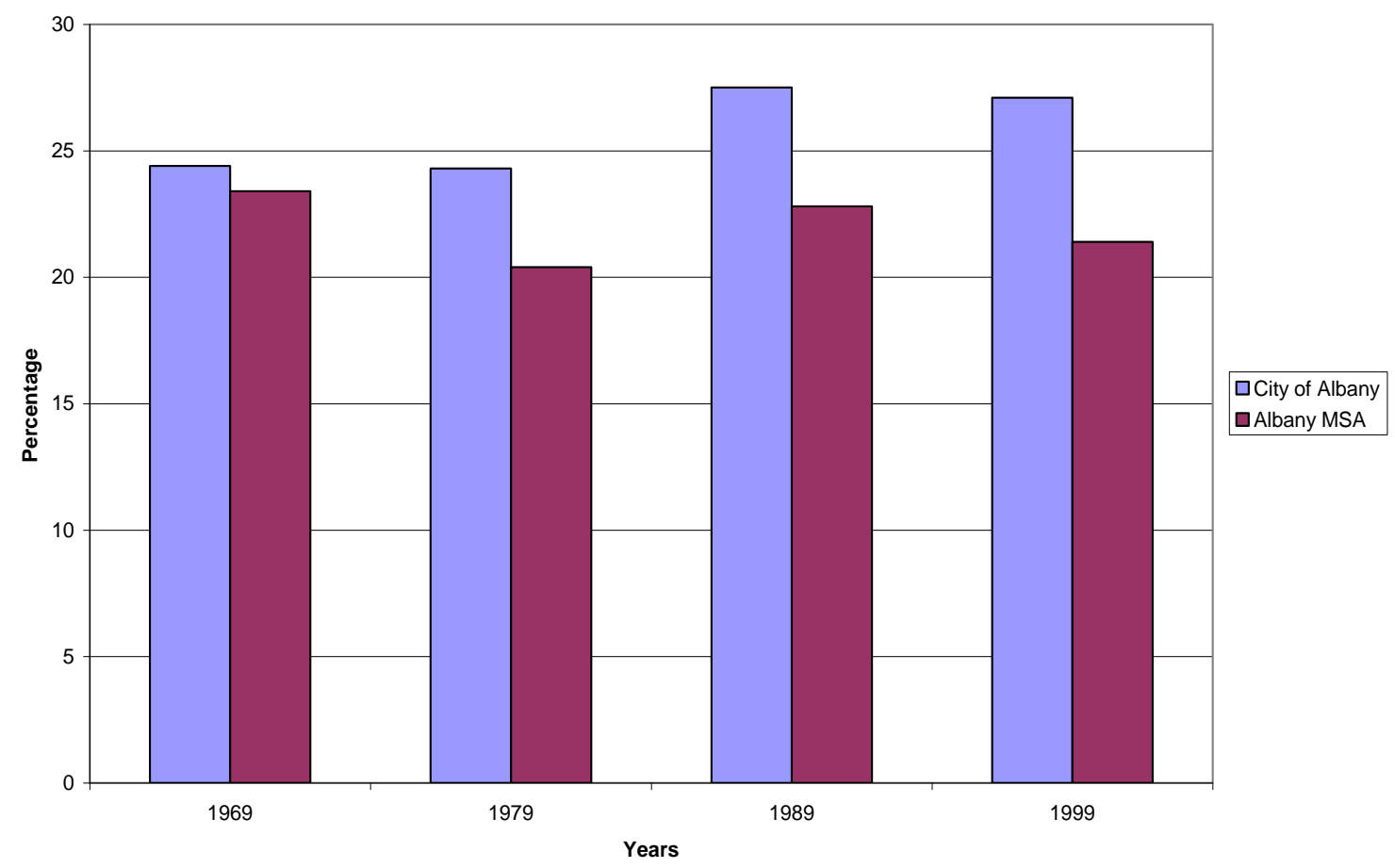

Just as unemployment rate predicts poverty, the poverty rate chart also highlights higher levels of poverty at the city level than at the Albany MSA level. This could be accounted for by the sources of poverty including the effect of the White relocation with their resources out of the county. The City bears the most brunt of resource relocation. Figure 4 shows the median family income in 2006 dollars $^{18}$.

\footnotetext{
${ }^{17}$ The poverty estimates are retrieved from: http://socds.huduser.org/Census/incpov.odb. There is no poverty rate series at the county level.

${ }^{18}$ The median family income estimates are retrieved from: http://socds.huduser.org/Census/incpov.odb. There is no median family income series at the county level.
} 
Figure 4: Median Family Income in 2006 Dollars

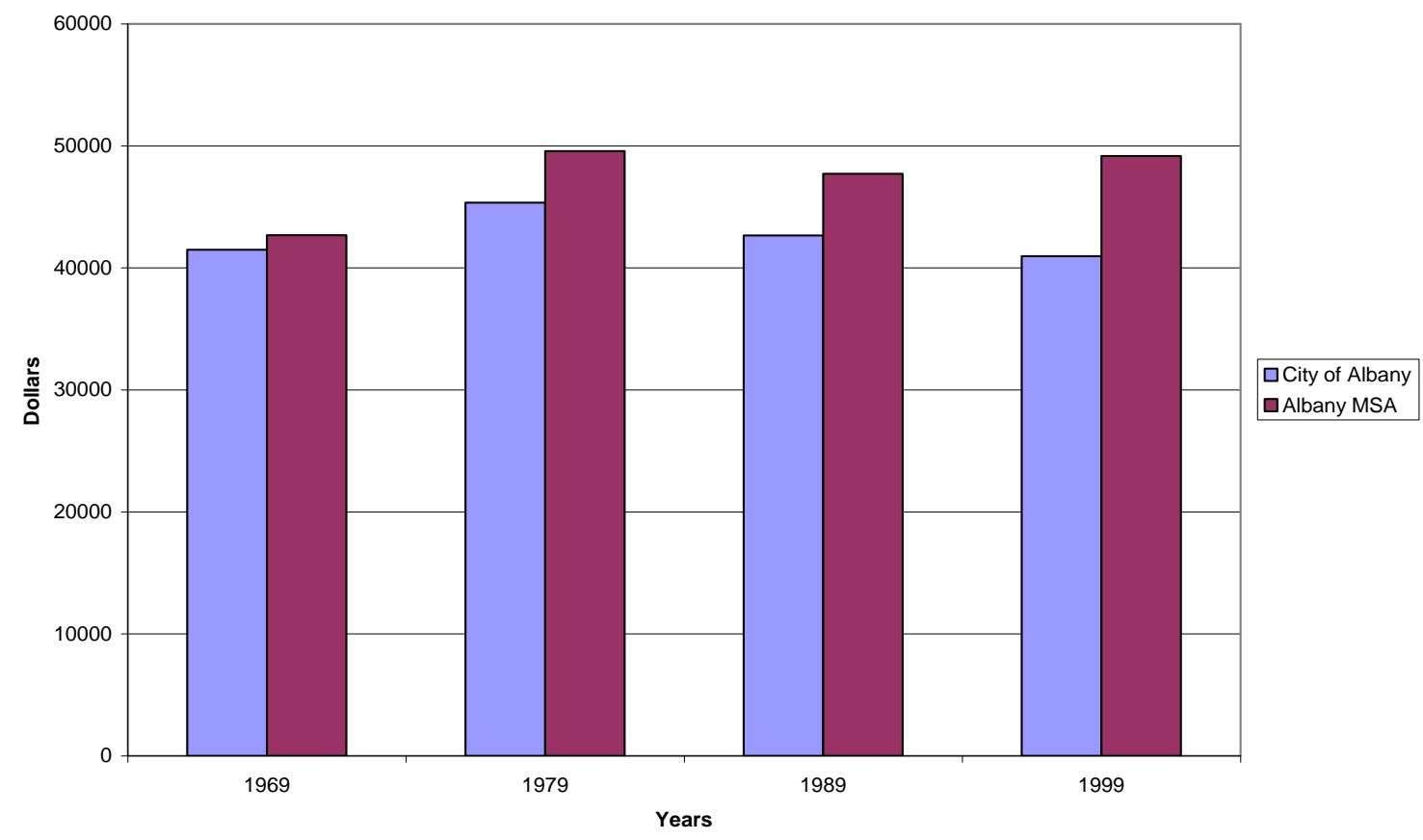

Yet another measure of poverty-median family income presents more income inequality at the city level than at the Albany MSA level. Consistently, all the poverty measurement indexes-unemployment and poverty rates, and median income clearly show economic stagnation and higher levels of income inequality at the micro levels.

\section{III.1. Basic Econometric Specifications}

Due to limitedness of data, multivariate statistical procedure could not be conducted. Running the procedure in the presence of this constraint would lead to a substantial loss of degree of freedom and the estimates of the parameters would be strictly insignificant. Also introduction of many dummy variables to the data, would lead to noisy data that would distort the realities in the Dougherty County. Given these constraints, the study provides scatter dots and correlation coefficients of the major series in the following tables (Table 2 and Table 3). The major series include the real average weekly wage earnings (wage), employment (Emp), establishments (Est), and the difference between the numbers of criminals admitted to and released from jail (Diff). 
Table 2: Scatter Dots

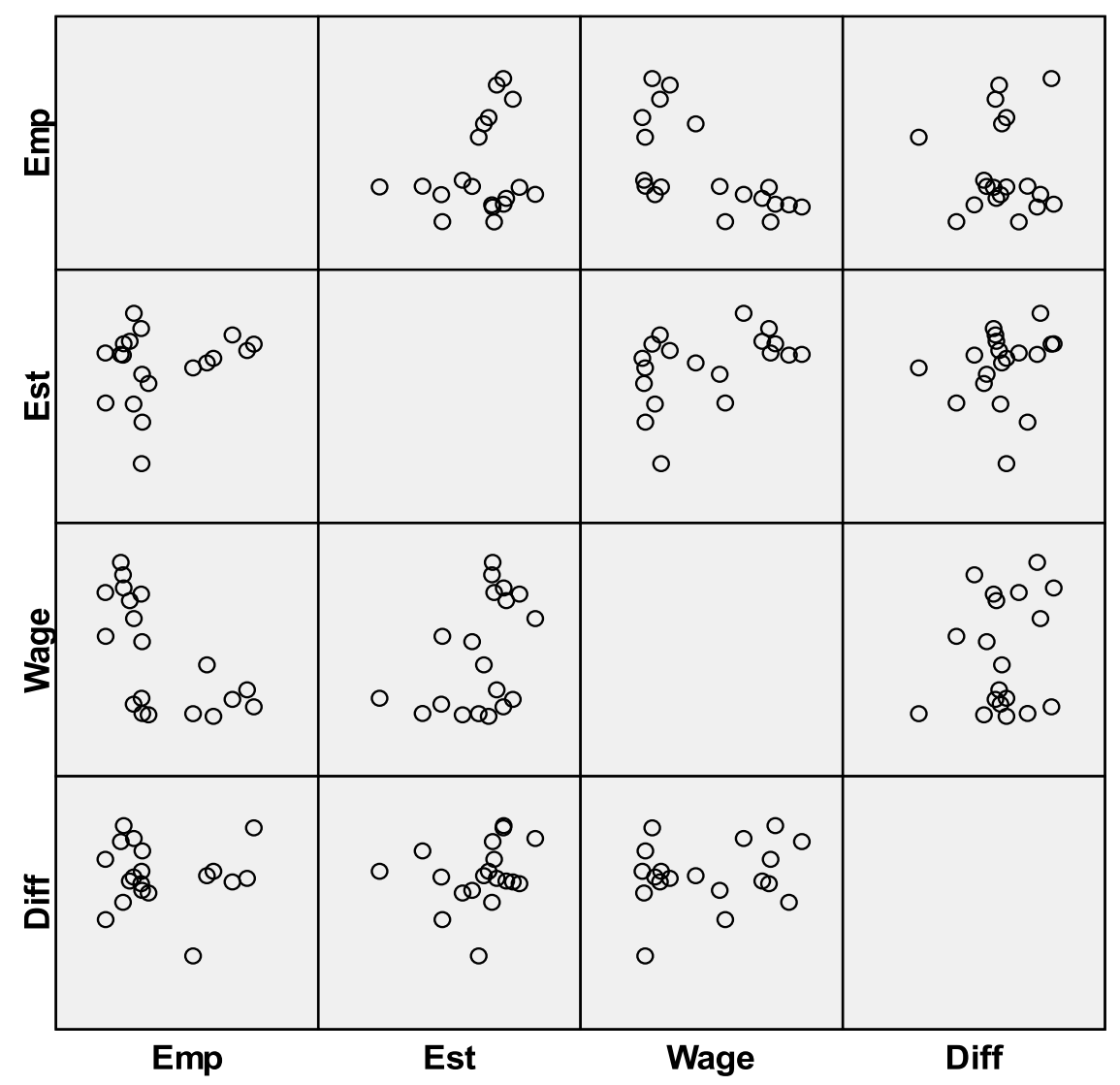

Cautiously speaking, there is some small positive trend between employment and establishments, and a negative trend between wage and employment.

The relationships between the variables are also apparent from the correlation coefficients in Table 3.

Table 3: Correlation

\begin{tabular}{|c|c|c|c|c|c|}
\hline & & Emp & Est & Wage & Diff \\
\hline \multirow[t]{3}{*}{ Emp } & Pearson Correlation & 1 & .227 & $-.627^{* *}$ & .001 \\
\hline & Sig. (2-tailed) & & .349 & .004 & .997 \\
\hline & $\mathrm{N}$ & 19 & 19 & 19 & 19 \\
\hline \multirow[t]{3}{*}{ Est } & Pearson Correlation & .227 & 1 & .440 & .207 \\
\hline & Sig. (2-tailed) & .349 & & .059 & .396 \\
\hline & $\mathrm{N}$ & 19 & 19 & 19 & 19 \\
\hline \multirow[t]{3}{*}{ Wage } & Pearson Correlation & $-.627^{* * *}$ & .440 & 1 & .212 \\
\hline & Sig. (2-tailed) & .004 & .059 & & .384 \\
\hline & $\mathrm{N}$ & 19 & 19 & 19 & 19 \\
\hline \multirow[t]{3}{*}{ Diff } & Pearson Correlation & .001 & .207 & .212 & 1 \\
\hline & Sig. (2-tailed) & .997 & .396 & .384 & \\
\hline & $\mathrm{N}$ & 19 & 19 & 19 & 19 \\
\hline
\end{tabular}

**. Correlation is significant at the 0.01 level (2-tailed). 
As expected from Dougherty County, most of the coefficients of the variables are not significant. The significant correlation coefficient between wage and employment (-.627) would suggest that an increase in the wage earning would decrease employment. This could also suggest that an attempt to increase employment would suppress the wage earning. For example, with other things remaining constant, if employment increases by one unit, wage earning would decrease by .627 .

\section{IMPLICATIONS ON MINORITY ENTREPRENEURSHIP TO DIMINISH POVERTY}

Entrepreneurship in the minority neighborhood is very low and restricted (Adams-Cooper 2011). The neighborhood does not seem to have market orientations and indicators to create businesses to effect reduction of unemployment rates. A limited minority's market entrepreneurship in essence, leads to minority dependence on majority for provision of employment. Insufficient levels of education, of human capital, and of management experience may account for the low level of the entrepreneurial activities. An entrepreneurial learning curve from these limited market norms would be expected to be relatively flat. The need to break vicious cycle of poverty does not seem to drive up the long run entrepreneurial consciousness in the county.

Access to capital spurs entrepreneurship and business creation. Having access to capital and possessing the ability to negotiate on the relative capital formation terms complement a state of an elevated entrepreneurial spirit. An impoverished environment could lead to various levels of indebtedness and defaults arising from consumer loans (Lardner and Smith 2005, p 74). Given this situation the capital formation terms can be extremely unfavorable to the would-be-entrepreneurs in the stratified economy. A lot of people may not prevail over this hurdle even if they harbor a great deal of human capital. Financial institutions have the tradition of requesting customers to have compensating balances in order to have access to loans for entrepreneurial activities. Higher levels of compensating balances can strongly diminish entrepreneurial activities especially in an impoverished economy.

High marginal propensity to consume (MPC) associated with the poor has its own disadvantage (Ballard 2008). Given that the poor spends at a faster rate than does the rich, the poor would have difficulty having access to capital most especially where there is a doubt that the poor will easily redirect business loans for capital formation to consumer expenditures. With this perception, the poor become very risky borrowers. In a situation where ostentatious purchases are associated with any particular cohort especially in poverty, it may become more difficult for the cohort to have access to capital. Also discrimination and segregation could also inhibit accessibility to productive capital.

Black business partnerships are generally not visible even in the restricted economy of East Albany with African American majority (Adams-Cooper, 2011). This challenge seems to support the argument of Richard Florida questioned in (Shane 2010) that demographic diversity promotes entrepreneurship. In this same restricted economy, various business partnerships are common only among people of other races who understand the values of entrepreneurship and partnership. Theory would have it that partnership brings into a business venture, new talents, increased financial resources, division of labor and specialization that are necessary to achieve a reasonable continuity in business (Samuelson \& Nordhaus, 2005, p 119). Business distrust can be minimized by legally drafting and adopting a document that has sufficient expression of all the terms. Some level of self interest can be sacrificed to achieve cooperation needed in partnerships that is necessary to underwrite the initial capital outlays to form businesses. Raising the initial capital outlay would require that some part of the current consumption be given up for investment in order to have higher levels of future consumption and for advancing opportunities for others.

Entrepreneurial theory would suggest that patience, responsibility, and commitment be exercised for one to expect the most benefit from a price driven economy. Patience enables an entrepreneur to accept the expected shortrun loses that is associated with business creation. Creative business risk takers understand that if the short-run costs can be predicted sufficiently and controlled that everyone would be entrepreneurs. Market entrepreneurs are constantly looking for opportunities to diminish costs in order to maximize profit by thinking at the margins. With this principle, the entrepreneur will observe the most gain with the activity level associated with where marginal return equals marginal cost. An entrepreneur must take responsibility for any outcome from enterprising activities. Losses have to be accepted just as profits are accepted as reward for being successful. There must be commitments to innovational efficiency to minimize wastes and inefficiencies. Only entrepreneurial process will minimize costs to enable a realization of the most profit given the constraints faced in any particular market. 


\section{CONCLUSION}

It is apparent that Dougherty County's economy is declining, and is magnifying poverty. Various indexes explain the poverty and limited opportunities in the county. The sources of poverty include the county's southern remote location, non harmonized regional development, crime, and dysfunctional education. As always the southern racial discrimination and segregation still create dualistic economies and prevent equal access to opportunities. The White rural migration puts a bold face on the poverty of the county that is divided by race and class. Cautiously speaking, these sources of poverty tend to cause the exit of the big establishments, a declining employment, and a slight increase in the real average weekly wage earning.

Educational achievement from the public school systems is unacceptable. Poverty alleviation in the county would also depend on qualitative, quantitative and mass adult education. Education at all levels-high school, technical and college must be emphasized for a real reform in order to achieve the competence required for both self and community development. The system must be driven by the needs of the students. Students will have to be placed on a particular educational standard based on some kind of standardized tests. Qualitative education will target entrepreneurial and leadership development while quantitative education will focus on advancing the technical skills and general awareness required for enhancing productivity and understanding of various exchanges in the contemporary free enterprise economy. Technical education has to strictly focus on skill acquisition in the face of changing technologies, procedures, and global competition. Adult mass education will enhance residents self selections and general quality of life.

The existing poverty alleviation initiatives would help but may not get to the root causes of the persistent poverty that is driven by non-market norms. Therefore, policy discussion must focus strictly on pragmatic market activities. An effective poverty reduction should encourage an increase in the level of exogenous establishments. These would have the multiplier effect that could induce a high level of economic development.

Given the rustic nature of the East Albany and persistent poverty in the county, it seems that any anticipated economic development has to be deliberately induced. Specialized micro-financial institutions need to be exogenously established especially in the impoverished environments. Among other functions, these establishments will provide concessionary small scale loans for financing businesses like mom and dad pubs. By tailoring programs suitable to the needs and aspirations of the poor, the poor could acquire market attributes to assess the costs and benefits of market participation. In the long run, poverty is most likely to be diminished when people increasingly understand the attributes of a market based economy and entrepreneurship.

\section{AUTHOR INFORMATION}

Dr. Amaechi N. Nwaokoro is an Associate Professor of Economics at Albany State University, Albany, Georgia. He earned a doctorate in economics from University of Oklahoma, a Masters of Business Administration from Oklahoma City University, and a bachelor degree in Business \& Economics from Northwestern Oklahoma State University. Dr. Nwaokoro has published more than half- a- dozen refereed journal articles and some conference proceedings. He is currently researching and writing manuscripts for publication. He has over ten years of continuous teaching experience at both undergraduate and graduate levels of economic education.

As a member of Southwestern Social Science Association, I review articles for Southwestern Journal of Economics, an affiliate of the Association. I have made various professional presentations during the meetings of this association. Economics is my passion and I also enjoy traveling. I derive joy doing charity work. This is another call that also requires my time here on earth. For more details about my background, research interests, publications, and work experience request for my full resume. Dr. Nwaokoro can be reached at $229-430-4723$ or email: Amaechi.nwaokoro@asurams.edu. 


\section{REFERENCES}

1. Adams-Cooper, V., 2010. "Addressing the Roots of Black Poverty in the United States: A Proposed Dual Macro-Micro, Niche-Market Network Systems Approach [White Paper]”. Albany, GA: VAAC Consulting Inc.

2. Bagi, Sukhwinder, 2008. "An Analysis of Inequality, Human Development, and Economic Growth”. Southwestern Journal of Economics, Vol. X, No. 2, 69-80.

3. Baldwin, Marjorie L. and William G. Johnson, 1996. "The Employment Effects of Wage Discrimination Against Black Men”. Industrial \& labor Relations Review, 302-316.

4. Black, Dan A. and John E. Garen, 1991. "Efficiency Wages and Equilibrium Wages". Economic Inquiry, 525-540.

5. Ballard, Bill 2008. "A Keynes/Post Keynesian Analysis of the Wealth". Presented at 2008 Southwestern Economics Association, Denver, Colorado, Working Paper.

6. Blitzer, Wolfe, February 10, 2010. The Situation Room. CNN Live.

7. Browne, Irene, 1997. "Explaining the Black-White Gap in Labor Force Participation Among Women Heading Households". American Sociological review, 236-252.

8. Castillo, Monica D. 1998. "Persons Outside the Labor Force Who Want A". Monthly Labor Review, 34-42. Couch, Kenneth and Mary C. Daly, 2002. "Black-white wage inequality in the 1990s: A Decade of Progress". Economic Inquiry, 31-41.

9. D'Amico, Ronald and Nan L. Maxwell, 1994. “The Impact of Post-School Joblessness on Male Black Wage Differentials". Industrial Relations, 184-205.

10. Davis et al, 2006. "The Flow Approach to Labor Markets: New Data Sources and Micro Macro Links". Journal of Economic Perspectives, 3-27.

11. Davis Alison F. and Simona Balazs, 2011. "Is Going Local a Sustainable Strategy for Communities". Southwestern Economic Association Working Paper, 1-2.

12. Dougherty County 2010. Races in Dougherty County, Georgia. Dougherty County.

13. Dougherty County School System. 2002-2009 DCSS Graduation \& Dropout Rates. Dougherty County School System. Albany, Georgia.

14. Dunne, Timothy and Mark J. Roberts, 1993. “The Long-Run Demand for Labor: Estimates from Census Establishment Data". U.S. Department of Commerce. Washington, D.C.

15. Farr, Jessica L. and Sibyl S. Slade. 2008. "Albany, Georgia: the East Albany Neighborhood". Albany Georgia.

16. Federal Reserve System 1990-2008. Moody's Seasoned AAA Corporate Bond Yield. Federal Reserve System.

17. Gardner, Jennifer M. and Diane E. Hern. 1992. "Working and Poor in 1990". Monthly Labor Review, 2028.

18. Georgia Bureau of Investigation 2010. Crime Statistics. Georgia Bureau of Investigation.

19. Georgia Department of Corrections 2010. Reports: Annual Statistics. Georgia Department of Corrections.

20. Georgia Department of Labor 1990-2008. Workforce Professionals: Historical Data. Georgia Department of Labor.

21. Gittleman, Maury and Edward N. Wolff, 2004. "Racial Differences in Patterns of Wealth Accumulation". The Journal of Human Resources, Vo. 39, No 1, 193-227.

22. Graham, Leigh. September 14, 2009. "White Recession, Black Depression" Change.org, 1-3.

23. Hodler, Thomas W. \& Howard A. Schretter 1986. "The Atlas of Georgia, The Institute of Community and Area Development"-The University of Georgia, USA.

24. Hoynes, Hilary W. et al., 2006. "Poverty in America: Trends and Explanations". Journal of Economic Perspectives, 47-68.

25. Khandker, Shahidur R., 2005. "Microfinance and Poverty: Evidence Using Panel Data from Bangladesh". The World Bank Economic Review Advance Access, 1-24.

26. Lardner, James and David Smith A., 2005. Inequality Matters: The Growing Economic Divide in America and its Poisonous Consequences. The New Press. New York.

27. Lui et al 2006. The Color of Wealth. The New York Press. New York

28. Morduch, Jonathan, 2002. “Analysis of the Effects of Microfinance on Poverty Reduction”. NYU Wagner Working Paper. Robert F. Wagner Graduate School of Public Service, New York University, 1-163. 
29. Mankiw, N. Gregory, 2008. Principles of Microeconomics, $5^{\text {th }}$ edition: South-Western Cengage Learning, USA.

30. O'Connell, Michael \& Hammad Sheikh 2008. "Achievement-related attitudes and the fate of "at-risk" groups in Society". Journal of Economic Psychology, 29 508-521,

31. Owen, James and John Martinez, 2008. "Income Inequality Trend in Texas". Working Paper, Midwestern State University

32. Riddell et al, 2011. Economics: A Tool for Critically Understanding Society. Pearson/Addison Wesley, San Francisco, California.

33. Schiller, Bradley R.2008. The Economics of Poverty and Discrimination. Pearson: Prentice Hall. Upper Saddle River, NJ.

34. Samuelson, Paul, William Nordhaus, 2005. Microeconomics. McGraw-Hill/Irwin. New York, NY.

35. Schmitt, John, 2004. "The Rise in Job Displacement, 1991-2004". Challenge, 46-68.

36. Smith, Ralph E. and Bruce Vavrichek 1987. "The minimum wage: its relation to incomes and poverty". Monthly Labor Review, 24-30.

37. SPSS Inc., 2010. SPSS Statistics 17.0 (2) SPSS Inc., An IBM Company Headquarters, Chicago, Illinois.

38. The University of Georgia, Terry College of Business, Selig Center for Economic Growth, 2009. Georgia Economic Outlook. Terry College of Business, Selig Center for Economic Growth.

39. Theodos, Brett and Robert Bednarzik, 2006. "Earnings Mobility and low-wage workers in the United States". Monthly Labor Review, 34-47. 